\title{
Upaya Meningkatkan Hasil Belajar Siswa dalam Pembelajaran PPKn melalui Model Pembelajaran Kooperatif TGT (Team Game Tournaments)
}

\author{
Eko Budi Sulistyo ${ }^{1}$, Nani Mediatati ${ }^{2}$ \\ ${ }^{1,2}$ PPKn - FKIP Universitas Kristen Satya Wacana \\ e-mail: eko1994budi@gmail.com ${ }^{1}$, mediatatin1@gmail.com²
}

\begin{abstract}
Abstrak
Penelitian ini bertujuan untuk mendeskripsikan peningkatan hasil belajar siswa kelas VIII B dalam pembelajaran PPKn melalui penggunaan model pembelajaraan kooperatif TGT (Teams Game Tournaments) di SMP N 1 Ambarawa Semester II Tahun Ajaran 2018/2019. Jenis penelitian merupakan penelitian tindakan kelas (PTK) yang dilaksanakan dalam dua siklus. Indikator keberhasilan penelitian ditentukan hasil belajar ranah kognitif dengan KKM $\geq 75$ dicapai oleh $90 \%$ dari 24 siswa kelas VIII B. Teknik pengumpulan data menggunakan observasi dan tes. Data dari hasil tes dianalisis dengan teknik deskriptif komparatif. Hasil penelitian menunjukkan bahwa penerapan model pembelajaran TGT (Team Game Tournaments) pada mata pelajaran PPKn dapat meningkatkan hasil belajar siswa dalam ranah kognitif pada siswa kelas VIII B SMP Negeri 1 Ambarawa tahun ajaran 2018-2019. Hal ini dapat ditunjukkan dari peningkatan ketuntasan hasil belajar siswa pada pra siklus ke siklus I dan siklus II. Pada pra siklus terdapat 8 siswa $(33,33 \%)$ yang mendapatkan nilai tuntas KKM $\geq$ 75 meningkat menjadi 19 siswa $(79,17 \%)$ pada siklus I,dan pada siklus II meningkat menjadi 24 siswa (100\%). Disamping itu penerapan model pembelajaran TGT juga dapat meningkatkan sikap dan perilaku siswa antara lain kerjasama / gotong-royong, tanggung jawab, dan demokratis.
\end{abstract}

Kata Kunci: Pelajaran PPKn, Hasil Belajar, Team Game Tournaments.

This study aims to describe the improvement in learning outcomes of class VIII B students in PPKn learning through the use of the cooperative learning model TGT (Game Tournaments Teams) in SMP N 1 Ambarawa Semester II Academic Year 2018/2019. This type of research is classroom action research (CAR) conducted in two cycles. The indicator of the success of the study was determined cognitive learning outcomes with KKM $\geq 75$ achieved by $90 \%$ of the 24 students of class VIII B. The technique of collecting data using observation and tests. Data from the test results were analyzed by a comparative descriptive technique. The results showed that the application of the TGT (Team Game Tournaments) learning model on PPKn subjects could improve student learning outcomes in the cognitive domain in class VIII B of SMP Negeri 1 Ambarawa in the academic year 2018-2019. This can be shown from the increase in completeness of student learning outcomes in the pre-cycle to cycle I and cycle II. In the pre cycle there were 8 students (33.33\%) who got the complete score of KKM $\geq 75$ increasing to 19 students (79.17\%) in the first cycle, and in the second cycle it increased to 24 students with (100\%). Besides that the application of the TGT learning model can also improve students' attitudes and behaviors including cooperation / mutual cooperation, responsibility, and democratic.

Keywords: Learning PPKn, Learning Outcomes, Game Tournaments Team 


\section{Pendahuluan}

Pendidikan merupakan usaha sadar dan terncana untuk mewujudkan suasana belajar dan proses pembelajaran agar peserta didik aktif mengembangkan potensi dirinya untuk memiliki ketrampilan spritual keagamaan, pengendalian diri, kepribadian, kecerdasan, akhlak mulia serta ketrampilan yang diperlukan bagi dirinya, masyarakat, bangsa dan bernegara (pasal 1 ayat 1 UU No. 20 tahun 2003). Efektivitas pencapaian dari tujuan pendidikan tersebut sangat ditentukan oleh bagaimana kemampuan dan ketrampilan guru dalam pelaksanaan proses pembelajaran di kelas, dan tujuan pendidikan tersebut tidak hanya diarahkan pada pengembangan aspek pengetahuan / kecerdasan tetapi juga ketrampilan dan sikap / kepribadian peserta didik. Pengembangan ketiga aspek tersebut juga merupakan tujuan dari mata pelajaran PPKn sebagaimana dinyatakan dalam pasal 77 ayat 1 huruf b PP No. 32 tahun 2013 yaitu bahwa mata pelajaran PPKn bertujuan untuk membentuk peserta didik menjadi manusia yang memiliki rasa kebangsaan dan cinta tanah air dalam konteks nilai dan moral pancasila, kesadaran berkonstitusi Undang-Undang Dasar Negara Republik Indonesia 1945, nilai dan semangat Bhinneka Tunggal Ika serta Komitmen Negara Kesatuan Republik Indonesia. Dalam pembelajaran PPKn perserta didik tidak hanya diharapkan menguasai mata pelajaran yang berupa pengetahuan, tetapi dapat mewujudkan dalam sikap dan perilaku seingga menjadi warga negara yang cakap, terampil, berkarakter sesuai nilai-nilai pancasila guna berpartisipasi aktif dalam kehidupan bermasyarakat, berbangsa dan bernegara. Untuk itu guru mata pelajaran PPKn dalam proses pembelajaran perlu menguasai dan menerapkan berbagai metode / model pembelajaran yang inovatif dan mengaktifkan peserta didik, yaitu model-model pembelajaran yang berpusat pada peserta didik dan bukan lagi model-model pembelajaran yang berpusat pada guru, sehingga dapat mengembangkan potensi peserta didik dalam ketiga aspek baik pengetahuan, sikap, dan ketrampilan. Namun demikian dalam kenyataan guru PPKn dalam proses pembelajaran masih sering menggunakan metode ceramah yang berpusat pada guru sehingga tidak menarik bagi siswa, siswa pasif yang akhirnya berakibat pada siswa tidak menguasai materi pelajaran dan hasil belajar siswa rendah dari aspek pengetahuan. Demikian juga pembelajaran dengan menggunakan metode ceramah tidak dapat mengembangkan sikap dan perilaku peserta didik misalnya kerjasama / gotongroyong, tanggung jawab, dan demokratis. Sebagaimana dinyatakan oleh Rochiati Wiriaatmadja $(2010,: 11)$ bahwa mutu pembelajaran PPKn saat ini masih jauh dari apa yang diharapkan yang berdampak pada rendahnya hasil belajar siswa. Salah satu penyebabnya adalah metode yang digunakan guru tidak sesuai dengan materi, tidak sesuai dengan kondisi kelas dan tidak menarik bagi siswa. Berbagai solusi atau cara penyelesaian melalui penerapan model-model pembelajaran inovatif juga sudah banyak dibahas dalam telaah penelitian akademik maupun pelatihan terhadap guru. Akan tetapi guru tidak dapat memahaminya dan mengaplikasikanya dalam pembelajaran.

Hal ini juga terjadi di SMP N 1 Ambarawa, berdasarkan hasil observasi terhadap pembelajaran PPKn terlihat bahwa guru masih menggunakan metode ceramah yang diselingi tanya jawab dalam menyampaikan materi pembelajaran, sehingga siswanya pasif, kurang memperhatikan guru, kurang tertarik pada pembelajaran sehingga siswa tidak dapat menguasai materi pembelajaran dengan baik. Hal ini ditunjukkan oleh hasil tes PPKn yang dilakukan pada akhir pembelajaran, hanya 8 siswa $(33,33 \%)$ yang mendapat nilai tuntas KKM $\geq 75$ dan 16 siswa $(66,66 \%)$ tidak tuntas KKM.

Berdasarkan permasalahan tersebut maka perlu dilakukan penelitian tindakan kelas (PTK) untuk meningkatkan hasil belajar siswa dengan menggunakan model pembelajaran kooperatif tipe TGT (Teams Game Tournaments). "Salah satu tipe model cooperative adalah teams games tournament (TGT) yang sangat menekankan pada pentingnya interaksi dalam tim" (Marianti :2017). Menurut Rosdiani (2013) model pembelajaran adalah seluruh rangkaian penyajian materi ajar yang meliputi segala aspek sebelum, sedang dan sesudah pembelajaran yang dilakukan guru serta segala fasilitas yang terkait yang digunakan secara langsung atau tidak langsung dalam proses belajar mengajar. "TGT memungkinkan siswa dapat belajar lebih relaks di samping menumbuhkan tanggung jawab, kerja sama, persaingan sehat, dan keterlibatan belajar (Kariyana, 2014). Purwandari (2017) mengatakan bahwa "dengan menerapkan model pembelajaran TGT di kelas diharapkan dapat menghilangkan anggapan siswa tentang pelajaran yang membosankan". Sudimahayasa (2015) mengatakan bahwa TGT menambahkan dimensi kegembiraan yang diperoleh dari penggunaan permainan.

Model pembelajaran kooperatif adalah model pembelajaran yang berwawasan konstruktivisme yang dapat menciptakan suasana belajar aktif pada siswa melalui belajar 
kelompok. Menurut Soleh (2017) penerapan model pembelajaran kooperatif tipe TGT mewujudkan siswa berperan aktif dan dapat belajar lebih tenang selain dapat memunculkan rasa tanggung jawab, kerjasama, persaingan antar timsecara sehat, dan ketertiban belajar, sehingga diharapkan dapat mengubah hasil belajar siswa ke arah yang lebih baik lagi. Menurut Irawan (2017) model pembelajaran kooperatif tipe TGT merupakan salah satu model pembelajaran yang menunjang adanya interaksi belajar antar siswa dan melibatkan siswa secara aktif di dalam proses pembelajaran. Oleh karena itu perlu diadakan penelitian tindakan kelas untuk membuktikan bahwa melalui model pembelajaran kooperatif tipe TGT dapat meningkatkan aktifitas dan hasil belajar matematika siswa dalam pembelajaran. Menurut Solihah (2016) dengan model pembelajaran TGT siswa yang pintar diusahakan dapat membantu siswa yang kurang, sedangkan bagi siswa yang relatif sudah menguasai materi diharapkan akan lebih memahami materi yang diajarkan. Dengan demikian, kegiatan belajar tidak hanya untuk siswa yang berkemampuan tinggi saja tetapi juga milik siswa yang berkemampuan rata-rata dan rendah. Keterlibatan siswa secara aktif dalam proses belajar mengajar tentu saja dapat menciptakan kondisi belajar menjadi lebih menyenangkan. Menurut Hamdani (2011:92), Teams Games Tournaments adalah salah satu tipe atau model pembelajaran kooperatif yang mudah diterapkan, melibatkan aktivitas seluruh siswa tanpa ada perbedaan status, melibatkan peran siswa sebagai tutor sebaya, dan mengandung unsur permainan dan reinforcement. Menurut Sugiartana (2013) model pembelajaran kooperatif tipe TGT akan dapat menguatkan ingatan siswa terhadap materi yang dipelajarinya, karena permainan akademik yang dialami siswa dalam tournament berfungsi sebagai tinjauan untuk memantapkan pemahaman siswa terhadap materi pembelajaran yang telah dipelajarinya sebelum siswa mengikuti tes individual. Menurut Darmayanti (2016) komponen-komponen yang terdapat pada model pembelajaran Teams Games Tournamen (TGT) adalah penyajian materi, tim, game, turnamen, dan penghargaan kelompok. Aktivitas belajar dengan permainan yang dirancang dalam pembelajaran kooperatif model TGT, memungkinkan siswa dapat belajar lebih rileks di samping menumbuhkan tanggung jawab, kerja sama, persaingan sehat, dan keterlibatan belajar. Langkah-langkah pembelajaran TGT menurut Slavin (2005:166-168) meliputi (1) presentasi kelas, ini merupakan pengajaran langsung dan diskusi dalam penyampaian materi dan pengenalan model TGT agar siswa benar benar memperhatikan dan dapat mengikuti kuis yang akan dilakukan; (2) tim, dibentik tim yang terdiri dari 4 siswa yang mewakili kelas dalam hal kinerja akademik, jenis kelamin, dan etnis. Fungsi dari tim ini adalah memastikan bahwa semua anggota tim benar benar belajar dan mempersiapkan tim untuk bisa mengerjakan kuis dengan baik; (3) game, terdiri atas pertanyaan-pertanyaan untuk menguji pengetahuan siswa yang diperoleh selama presentasi kelas. Game tersebut dimainkan dimeja dengan tiga orang siswa yang masing-masing mewakilia tim yang berbeda ; (4) turnamen, yaitu sebuah struktur dimana game berlangsung yang dilakukan pada akhir unit setelah guru memberikan presentasi kelas dan tim telah melakukan kerja kelompok; (5) rekognisi tim, tim akan mendapat penghargaan apabila skor rata-rata mereka mencapai kriteria tertentu. Dengan langkah-langkah pembelajaran tersebut model TGT mampu menciptakan suasana belajar yang menarik dan memotifasi siswa untuk aktif dan bersemangan dalam mengikuti pembelajaran. Sebagaimana dinyatakan Asyirint (2010:65) bahwa keunggulan dari model Teams Game Tournaments adalah (1) kegiatannya bersifat kompetisi; (2) kegiatan dengan belajar dan diskusi secara menyenangkan seperti dalam kondisi permainan; (3) aktivitas belajar memungkinkan siswa untuk dapat belajar lebih rileks; dan (4) aktivitas dapat menumbuhkan tanggung jawab, kerjasama, persaingan sehat, dan keterlibatan belajar.

Beberapa hasil penelitian sebelumnya telah membuktikan keberhasilan penerapan model TGT (Teams Game Tournaments) dalam meningkatkan hasil belajar siswa. Mayasari, Malisa Dewi (2008), dalam penelitiannya yang berjudul Penerapan Pembelajaran Kooperatif Model TGT untuk Meningkatkan Hasil Belajar Siswa pada Mata Pelajaran PKn Kelas IV SDN Ngrami I menunjukkan bahwa, pelaksanaan pembelajaran PKn dengan menerapkan model TGT (Teams Game Tournaments) dapat meningkatkan aktivitas belajar dan hasil belajar siswa pada mata pelajaran PKn kelas IV SDN Ngrami I Kecamatan Sukomoro Kabupaten Nganjuk dengan data sebagai berikut, dari rerata skor 67,92 dan daya serap klasikal $16 \%$ pada pra tindakan dan setelah pelaksanaan tindakan mengalami peningkatan dengan rerata skor 70 dan daya serap klasikal $54 \%$ pada siklus I, kemudian rerata skor 87,2 dan daya serap $88 \%$ pada siklus II. Selaras dengan itu penelitian Muji Kuwati (2012) Model Pembelajaran Teams Game Tournaments (TGT) dalam peningkatan pembelajaran PKn siswa kelas IV SD N weton kulon suring kebumen. Hasil penelitiannya menunjukkan bahwa terdapat peningkatan hasil belajar 
siswa kelas IV SDN Weton Kulin Puring Kebumen, dari siklus I rata-rata 68,57 ke siklus II rata rata hasil belajar siswa 70,43 dan ke siklus III rata-rata hasil belajar siswa menjadi 80,06.

Berdasarkan latar belakang diatas, maka dilakukan penelitian tindakan kelas (PTK) untuk meningkatkan hasil belajar siswa dalam pembelajaran PPKn melalui penerapan metode pembelajaran TGT (Team Game Tournaments), dengan judul:"Upaya Meningkatkan Hasil Belajar Siswa Dalam Pembelajaran PPKn Melalui Model Pembelajaran Kooperatif TGT (Team Game Tournaments) Pada Siswa Kelas VIII B SMP N 1 Ambarawa Semester II Tahun Ajaran 2018/2019"

\section{Metode}

Penelitian tindakan kelas ini dilaksanakan di SMP N 1 Ambarawa dengan subyek penelitian siswa kelas VIII B yang berjumlah 24 siswa. Penelitian dilaksanakan dalam dua siklus, dan setiap siklus meliputi 4 tahapan yaitu: 1) perencanaan, 2) pelaksanaan tindakan, 3) observasi dan 4) refleksi. (Arikunto,2010:137)

Teknik pengumpulan data menggunakan teknik observasi dan tes. Analisis data menggunakan teknik deskriptif komparatif (Sugiyono,2006:68). Indikator keberasilan penelitian ini adalah $90 \%$ dari jumlah siswa kelas VIII B mendapatkan nilai tuntasKKM $\geq 75$.

\section{Hasil dan Pembahasan}

Sebelum melaksanakan tindakan, peneliti melakukan kegiatan observasi, terhadap pembelajaran dikelas dan studi dokumentasi terhadap nilai tes/ ulangan sehingga didapatkan data hasil belajar siswa yang dapat dilihat pada tabel berikut ini.

Tabel 1. Hasil belajar siswa sebelum tindakan (Pra Siklus)

\begin{tabular}{ccccc}
\hline \multirow{2}{*}{ No } & \multirow{2}{*}{ Nilai } & \multicolumn{2}{c}{ Sebelum Tindakan } & \multirow{2}{*}{ Keterangan } \\
\cline { 3 - 4 } & & Jumlah siswa & $\mathbf{( \% )}$ & \\
\hline 1 & $<65$ & 11 & $45,84 \%$ & Tidak Tuntas \\
2 & $65-69$ & 2 & $8,33 \%$ & Tidak Tuntas \\
3 & $70-74$ & 3 & $12,50 \%$ & Tidak Tuntas \\
4 & $75-79$ & 6 & $25,00 \%$ & Tuntas \\
5 & $80-84$ & 2 & $8,33 \%$ & Tuntas \\
\hline \multicolumn{2}{r}{ Jumlah } & $\mathbf{2 4}$ & $\mathbf{1 0 0 , 0 0 \%}$ & \\
\hline Nilai Rata-Rata & & 63,37 & \\
Nilai Tertinggi & & 80 & \\
Nilai Tesrendah & & 40 & \\
\hline
\end{tabular}

Berdasarkan pada tabel 01 di atas dapat diketahui nilai siswa yang tuntas KKM sebesar $33,33 \%$ (8 siswa) dan tidak tuntas KKM 66,67\% (16 siswa). Nilai siswa yang berada pada rentang $<65$ sebanyak 11 siswa $(45,84 \%), 2$ siswa(8,33\%) pada rentang $65-69$, kemudian 3 siswa $(12,50 \%)$ pada rentang $70-74,6$ siswa $(25,00 \%)$ berada pada rentang $75-79$ dan sisanya 2 siswa (8,33\%) mendapat nilai pada rentang $80-84$. Nilai rata-rata adalah 63,37 , nilai tertinggi 80 dan nilai terendah adalah 40 .

Dari data tersebut terlihat bahwa hasil belajar siswa sebagian besar masih rendah (belum tuntas KKM). Hal ini disebabkan karena dalam penyampaian materi guru masih menggunakan metode ceramah diselingi tanya jawab dan hanya menggunakan buku LKS, sehingga membuat suasana pembelajaran tidak menarik dan siswa pasif. Dengan kondisi tersebut berdampak pada hasil belajar siswa yang rendah karena siswa kurang menguasai materi pembelajaran. Oleh karena itu dilakukan perbaikan pembelajaran dengan menggunakan model pembelajaran TGT (Team Game Tournaments) yang dilaksanakan dalam 2 siklus.

Setelah dilaksanakan tindakan perbaikan pembelajaran dengan modelpembelajaran TGT (Team Game Tournaments) dalam mata pelajaran PPKn terjadi peningkatan hasil belajar siswa pada siklus I yang dapat dilihat dalam Tabel dibawah ini: 
Tabel 2. Hasil belaja Siklus I

\begin{tabular}{|c|c|c|c|c|}
\hline \multirow{2}{*}{ No } & \multirow{2}{*}{ Nilai } & \multicolumn{2}{|c|}{ SIKLUS I } & \multirow{2}{*}{ Keterangan } \\
\hline & & Jumlah siswa & $(\%)$ & \\
\hline 1 & $<65$ & 1 & $4,17 \%$ & Tidak Tuntas \\
\hline 2 & $65-69$ & 4 & $16,67 \%$ & Tidak Tuntas \\
\hline 3 & $70-74$ & 0 & $0,00 \%$ & Tidak Tuntas \\
\hline 4 & $75-79$ & 12 & $50,00 \%$ & Tuntas \\
\hline 5 & $80-85$ & 7 & $29,17 \%$ & Tuntas \\
\hline \multicolumn{2}{|c|}{ Jumlah } & 24 & $100,00 \%$ & \\
\hline \multicolumn{2}{|c|}{ Nilai Rata-Rata } & \multicolumn{3}{|c|}{75,58} \\
\hline \multicolumn{2}{|c|}{ Nilai Tertinggi } & \\
\hline \multicolumn{2}{|c|}{ Nilai Terrendah } & \multicolumn{3}{|c|}{$\begin{array}{l}82 \\
60\end{array}$} \\
\hline
\end{tabular}

Berdasarkan Tabel di atas dapat dilihat bahwa banyaknya siswa yang mencapai nilai KKM $\geq 75$ berjumlah 19 siswa(79,17\%), dengan rincian 12 siswa (50\%) mendapatkan nilai pada rentang 75-79 dan 7 siswa $(29,17 \%)$ berada di rentang $80-84$. Sedangkan sisanya sejumlah 5 siswa $(20,83 \%)$ belum mencapai KKM $\geq 75$ dengan rincian terdapat 1 siswa $(4,16 \%)$ yang nilainya dibawah rentang $<65$ dan 4 siswa (16,67\%). yang berada di rentang 65-69.

Nilai rata-rata 75,58 , nilai tertinggi 82 , dan nilai terendah 60 . Prosentase ketuntasan hasil belajar sebesar $79,17 \%$, belum sesuai dengan indikator keberhasilan dalam penelitian ini yaitu sebesar $90 \%$ dari 24 siswa tuntas KKM sehingga penelitian dilanjutkan pada siklus ke-II.

Setelah dilakukan perbaikan pembelajaran pada siklus II dengan tetap menggunakan model pembelajaran TGT (Team Games Tournaments) terjadi peningkatan hasil belajar siswa yang dapat dilihat dalam Tabel dibawah ini..

Tabel 3. Hasil Belajar Siswa Pada Siklus II

\begin{tabular}{|c|c|c|c|c|}
\hline \multirow{2}{*}{ No } & \multirow{2}{*}{ Nilai } & \multicolumn{2}{|c|}{ SIKLUS I } & \multirow{2}{*}{ Keterangan } \\
\hline & & Jumlah siswa & (\%) & \\
\hline 1 & $<65$ & 0 & $0,00 \%$ & Tidak Tuntas \\
\hline 2 & $65-69$ & 0 & $0,00 \%$ & Tidak Tuntas \\
\hline 3 & $70-74$ & 0 & $0,00 \%$ & Tidak Tuntas \\
\hline 4 & $75-79$ & 8 & $33,33 \%$ & Tuntas \\
\hline 5 & $80-84$ & 10 & $41,66 \%$ & Tuntas \\
\hline 6 & $85-89$ & 5 & $20,83 \%$ & Tuntas \\
\hline 7 & $90-94$ & 1 & $4,18 \%$ & Tuntas \\
\hline \multicolumn{2}{|c|}{ Jumlah } & 24 & $100,00 \%$ & \\
\hline \multicolumn{2}{|c|}{ Nilai Rata-Rata } & \multicolumn{3}{|c|}{81,5} \\
\hline \multicolumn{2}{|c|}{ Nilai Tertinggi } & \multicolumn{3}{|c|}{90} \\
\hline \multicolumn{2}{|c|}{ Nilai Terrendah } & \multicolumn{3}{|c|}{75} \\
\hline
\end{tabular}

Berdasarkan Tabel di atas dapat dilihat bahwa banyaknya siswa yang mencapai nilai $\mathrm{KKM} \geq 75$ berjumlah 24 siswa dengan prosentase 100\%, dengan rincian $8(33,333 \%)$ siswa mendapatkan nilai di rentang 75-79, 10 siswa (41,66\%), berada di rentang 80-84 dan 5 $(20,83 \%)$ siswa rentang $85-89$, dan 1 siswa $(4,18 \%)$ rentang $90-94$. rata-rata kelas 81,5 , denga nilai tertinggi 90 dan nilai terendah 75 . Berdasarkan tabel 0.3 diatas menunjukkan bahwa dengan persentase ketuntasan hasil belajar sebesar 100\%, dapat dikatakan penelitian yang dilakukan berhasil karena dapat meningkatkan hasil belajar siswa melampaui indikator keberhasilan yang sudah ditetapkan yaitu $90 \%$. Perbandingan ketuntasan hasil belajar siswa sebelum tindakan dan setelah dilakukan tindakan dalam 2 siklus dapat dilihat dalam tabel berikut ini. 
Tabel 4. Perbandingan ketuntasan hasil belajar siswa pada Pra Siklus, Siklus I, Siklus II

\begin{tabular}{|c|c|c|c|c|c|c|c|}
\hline \multirow{2}{*}{ No } & \multirow{2}{*}{ Nilai } & \multicolumn{2}{|c|}{ Pra Siklus } & \multicolumn{2}{|c|}{ Siklus 1} & \multicolumn{2}{|c|}{ Siklus 2} \\
\hline & & $\begin{array}{c}\text { Jumlah } \\
\text { Siswa }\end{array}$ & $\begin{array}{l}\text { Presentas } \\
\text { e (\%) }\end{array}$ & $\begin{array}{c}\text { Jumlah } \\
\text { Siswa }\end{array}$ & $\begin{array}{l}\text { Presentas } \\
\text { e (\%) }\end{array}$ & $\begin{array}{c}\text { Jumlah } \\
\text { Siswa }\end{array}$ & $\begin{array}{c}\text { Presentas } \\
\text { e (\%) }\end{array}$ \\
\hline 1 & Tuntas & 8 & $33,33 \%$ & 19 & $79,17 \%$ & 24 & $100,00 \%$ \\
\hline 2 & Tidak Tuntas & 16 & $66,66 \%$ & 5 & $20,84 \%$ & 0 & $0,00 \%$ \\
\hline 3 & Nilai Rata-Rata & \multicolumn{2}{|c|}{63,37} & \multicolumn{2}{|r|}{75,58} & \multicolumn{2}{|r|}{81,5} \\
\hline 4 & Nilai Tertinggi & \multicolumn{2}{|c|}{80} & \multicolumn{2}{|r|}{82} & \multicolumn{2}{|r|}{90} \\
\hline 5 & Nilai Terendah & \multicolumn{2}{|c|}{40} & \multicolumn{2}{|r|}{60} & \multicolumn{2}{|r|}{75} \\
\hline
\end{tabular}

Dari Tabel 4, di atas nampak bahwa hasil belajar siswa dari pra siklus ke siklus I dan ke siklus II menunjukkan adanya peningkatan.Nilai rata-rata hasil belajar siswa yang semula pada Pra siklus sebesar 63,37 meningkat pada siklus 1 menjadi 75,58, dan pada siklus 2 meningkat lagi menjadi 90.Ketuntasan hasil belajar siswa juga meningka pada pra siklus sebanyak 8 siswa $(33,33 \%)$, tuntas $\mathrm{KKM} \geq 75$ meningkat pada siklus 1 sebanyak 19 siswa(79,17\%), kemudian pada siklus 2 mengalami meningkat kembali sebanyak 24 siswa dengan prosentase $100 \%$. Dari hasil tersebut dapat disimpulkan bahwa metode pembelajaran TGT (Team Game Tournaments) berhasil meningkatkan hasil belajar siswa..

\section{A. Pra Siklus}

Hasil belajar siswa pada kondisi awal atau pra siklus dimana hasil belajar siswa masih rendah terlihat hanya 8 siswa yang memenuhi KKM $\geq 75$ dan sisanya 16 siswa tidak tuntas KKM $\geq 75$. Hal ini disebabkan oleh guru yang masih dominan menggunakan metode pembelajaran ceramah dimana siswa hanya mendengarkan tidak terlibat langsung dalam proses pembelajaran sehingga banyak siswa yang merasa bosan dan cenderung pasif untuk mengajukan pertanyaan ataupun untuk mengatakan bahwa materi yang disampaikan tidak di mengerti.

Dengan kondisi tersebut peneliti kemudian memilih metode pembelajaran yang sesuai dengan karakteristik siswa didalam kelas yaitu menggunakan metode pembelajaran TGT (Team Game Tournaments) dengan harapan metode ini dapat meningkatkan hasil belajar siswa dalam mata pelajaran PPKn di kelas VIII B SMP Negeri 1 Ambarawa. Berdasarkan penelitian tindakan kelas yang dilaksanakan di SMP Negeri 1 Ambarawa semester II melalui penerapan metode pembelajaran TGT (Team Game Tournaments) terbukti dapat meningkatkan hasil belajar siswa yang dapat dilihat dari jumlah siswa yang mencapai nilai ketuntasan belajar $\geq 75$.

\section{B. Siklus I}

Pelaksanaan kegiatan siklus I dilaksanakan pada tanggal 23 dan 30 Januari 2019, didalam pelaksanaanya siklus I terbagi menjadi 2 pertemuan dan setiap pertemuan memiliki alokasi waktu 80 menit. Hasil evaluasi pada siklus ke I menunjukkan adanya peningkatan hasil belajar siswa dimana pada pra siklus siswa yang mendapatkan nilai tuntas KKM $\geq 75$ sebanyak 8 siswa ataui 33,33 \% meningkat menjadi 19 siswa atau $79,17 \%$. Nilai terendah 60 , nilai tertinggi 82 , dan nilai rata-rata 75,58 .

\section{Siklus II}

Pelaksanaan siklus II dilaksanakan pada tanggal 6 dan 13 pebuari pada siklus ke II juga dilakukan 2 kali pertemuan dimana alokasi setiap pertemuan 80 menit. Berdasarkan hasil evaluasi menunjukkan bahwa hasil belajar siswa kelas VIII B SMP Negeri 1 Ambarawa pada siklus II, mengalami kenaikan yang signifikan dari 24 siswa semuanya mendapatkan nilai tuntas KKM $\geq 75$ atau dalam prosentase $100 \%$. Nilai terendah adalah 75 , nilai tertinggi 90 ., dan nilai rata-rata 81,50 Dari hasil siklus II ini telah melebihi indikator capaian keberhasilan penelitian yaitu sebesar $90 \%$. Dengan demikian dapat disimpulkan bahwa penerapan metode pembelajaran TGT (Team Game Tournaments) dalam mata pelajaran PPKn yang dilaksanakan di SMP Negeri 1 Ambarawa pada kelas VIII B semester II tahun ajaran 20182019 telah berhasil meningkatkan hasil belajar siswa. 


\section{Simpulan dan Saran}

Berdasarkan hasil penelitian yang sudah dilakukan maka dapat disimpulkan bahwa penerapan model pembelajaran TGT (Team Game Tournaments) pada mata pelajaran PPKn dapat meningkatkan hasil belajar siswa dalam ranah kognitif dikelas VIII B SMP Negeri 1 Ambarawa tahun ajaran 2018-2019. Hal ini ditunjukkan dari peningkatan ketuntasan hasil belajar pada pra siklus, ke siklus I dan siklus II. Pada pra siklus terdapat 8 siswa $(33,33 \%)$ tuntas KKM $\geq 75$ meningkat menjadi 19 siswa $(79,17 \%)$, pada siklus I dan pada siklus II meningkatmenjadi 24 siswa (100\%). Disamping itu penerapan model TGT juga dapat meningkatkan sikap kerjasama atau gotongroyong, tanggung jawab, dan demokratis dari siswa.

\section{Daftar Pustaka}

Arikunto, S dan Suhardjono. 2009. Penelitian Tindakan Kelas. Jakarta: Bumi aksara.

Binti Maunah, 2009. Landasan Pendidikan. Yogyakarta: Teras.

Darmayanti K. A., N. Dantes, dan D. P. Parmiti. 2016. Pengaruh Model TGT terhadap Hasil Belajar Matematika dengan Kovariabel Kemampuan Numerik pada Siswa Kelas V. eJournal PGSD Universitas Pendidikan Ganesha Jurusan PGSD Vol: 4 No: 1 Hal. 1 -10. Tersedia Pada : https://ejournal.undiksha.ac.id/index.php/JJPGSD/.

Gustaf, Asyirint. 2010. Langkah Cerdas Menjadi Guru Sejati Berprestasi. Yogyakarta: Bahtera Buku.

Huda, Miftahul. 2014. Model-Model Pengajaran dan Pembelajaran. Pustaka Pelajar. Yogyakarta.

Hamdani. 2011. Strategi Belajar Mengajar. Bandung: Pustaka Setia.

Irawan, Agus. 2017. Model Pembelajaran Kooperatif Tipe Team Game Tournament (TGT) untuk Meningkatkan Aktivitas dan Hasil Belajar Matematika Siswa. Jurnal Edumath, Volume 3 No. 2 Hal. 164-170. Tersedeia Pada : https://ejournal.stkipmpringsewuIpg.ac.id/index.php/edumath/article/view/461.

Kariyana, I Kadek.2014 "Implementasi Pembelajaran Kooperatif TGT untuk Meningkatkan Aktivitas dan Hasil Belajar Dribbling Sepakbola”. Jurnal Penjakora Vol 2 No 12014 (111).

Marianti dan Ratnawati Susanto 2017. "Pengaruh Model Cooperative Learning Tipe Teams Games Tournament (TGT) terhadap Kecerdasan Interpersonal Pada Mata Pelajaran IPS". Jurnal Ilmiah Sekolah Dasar Vol.1 (4) pp. 260-269.

Purwandari, Amanda \& Dyah Tri Wahyuningtyas. 2017. "Eksperimen Model Pembelajaran Teams Games Tournament (TGT) Berbantuan Media Keranjang Biji-Bijian terhadap Hasil Belajar Materi Perkalian dan Pembagian Siswa Kelas II SDN Saptorenggo". Jurnal Ilmiah Sekolah Dasar. Vol.1 (3) pp. 163-170.

Rosdiani, Khairil, dan Cut Nurmaliah. 2013. Penerapan Model Pembelajaran Kooperatif Tipe Team Games Tournament (TGT) Berbasis Praktikum terhadap Penguasaan Konsep Sistem Pencernaan Manusia Di SMA Negeri 1 Sigli. Jurnal Biologi Edukasi Edisi 11, Vol. 5 No. 2 Hal. 66-71. Tersedia Pada : http://jurnal.unsyiah.ac.id/JBE/article/view/1221.

Soleh, Maulana Ibnu, Dadang Kurnia, Dede Tatang Sunarya. 2017. Penerapan Model Pembelajaran Kooperatif Tipe Teams Games Tournament (TGT) pada Pembelajaran PIPS untuk Meningkatkan Hasil Belajar Siswa pada Materi Sumber Daya Alam dan Kegiatan Ekonomi. Jurnal Pena IImiah: Vol 2, No 1 Hal 2101-2110. Tersedia Pada : http://ejournal.upi.edu/index.php/penailmiah/article/download/12416/7374. 
Solihah, Ai. 2016. Pengaruh Model Pembelajaran Teams Games Tournament (TGT) terhadap Hasil Belajar Matematika. Jurnal SAP Vol. 1 No. 1 Hal. 45-53. https://journal.Ippmunindra.ac.id/index.php/SAP/article/view/1010/0.

Sudimahayasa, Nyoman. 2015. "Penerapan Model Pembelajaran TGT Untuk Meningkatkan Hasil Belajar, Partisipasi, dan Sikap Siswa". Jurnal Pendidikan dan Pengajaran, Jilid 48, Nomor 1-3, April 2015, hlm. 45-53.

Sugiartana, Md. Slamet, Dw. Nym Sudana, dan Ni Wyn. Arini. 2013. Penerapan Model TGT untuk Meningkatkan Hasil Belajar IPA dan Sikap IImiah Siswa Kelas VB SD Negeri 3 Banjar Jawa. e-Journal PGSD Universitas Pendidikan Ganesha Jurusan PGSD Vol: 1 $\begin{array}{llllll}\text { No: } & 1 & \text { Hal. } & 1 & -10 & \text { Tersedia }\end{array}$ https://ejournal.undiksha.ac.id/index.php/JJPGSD/article/view/871/743.

Wiriaatmadja, Rochayanri. 2010. Metode Penelitian Tindakan Kelas. Bandung: PT Remaja Rosdakarya. 